\title{
INFLUENCE OF LAND USE AND OCCUPATION IN THE QUALITY OF SURFACE WATER IN THE PARAGUAI/ DIAMANTINO BASIN, MATO GROSSO, BRAZIL
}

\author{
Adriana Ferreira LIMA ${ }^{1}$ \\ Edinéia Aparecida dos Santos GALVANIN ${ }^{2}$ \\ Sandra Mara Alves da Silva NEVES ${ }^{3}$ \\ Danielle STORCK-TONON ${ }^{1}$
}

\begin{abstract}
This study aims to evaluate the influence of land use and occupation at different scales on the quality of surface water of the Paraguay/Diamantino basin, Mato Grosso State, Brazil. Statistical tests were used to verify if there is a difference between scales at each point. Land use and land occupation analysis was performed using images from the RapidEye satellite. An unsupervised classification of the images was performed, and three classes of land use were defined: Evergreen Seasonal Forest, Cerrado and Anthropic Uses. Using ArcGIS software, the scales were defined using the multibuffer tool with radius of 50, 500 and 1000 meters in the vicinity of each sample point. The sample collections were of the simple type, on surface in 9 points of the main tributaries of the basin. ANOVA indicated a significant difference of turbidity in the rain and drought periods, which did not occur with the Total Solids. The analysis indicated a negative correlation between total Solids and the Evergreen Seasonal Forest class. They also showed a similarity in relation to Total Solids and Turbidity, being influenced by the spatial distance between the points.
\end{abstract}

Key words: Scale. Paraguay River. Image processing. Water quality.

\footnotetext{
1 UNEMAT - University Campus Tangará da Serra. Postgraduate Program in Environment and Agricultural Production Systems. Rod. MT 358 Km 07 PO Box 287, Jardim Aeroporto. Zip Code: 78.300-000 - Tangará da Serra - Mato Grosso, Brazil. E-mails: lima.adrianaferreira87; danistorck@gmail.com

2 UNEMAT - University Campus Barra do Bugres. Mathematics Department. Street A, S / n, Cohab São Raimundo. Zip Code: 78390-000 - Barra do Bugres - Mato Grosso, Brazil. E-mails: galvaninbbg@unemat.br

${ }^{3}$ UNEMAT - LABGEO - Laboratory for Geo-technologies. University of Mato Grosso State/ Geography Course. Av. Santos Dumont, Block 1, Room 09. Santos Dumont - University City. Zip Code: 78000-200 Cáceres / MT, Brazil.E-mail: ssneves@unemat.br
} 


\section{Resumo}

\section{Influência do uso e ocupação da terra na qualidade da água superficial da bacia Paraguai/Diamantino, Mato Grosso, Brasil}

Este estudo tem como objetivo avaliar a influência do uso e cobertura da terra em diferentes escalas, sobre a qualidade da água superficial da bacia Paraguai/ Diamantino, Mato Grosso, Brasil. Para verificar se há diferença entre as escalas em cada ponto procedeu-se a utilização de testes estatísticos. A análise do uso e cobertura da terra foi realizada por meio do uso de imagens do satélite RapidEye. Foi realizada a classificação não supervisionada das imagens, sendo definidas três classes de uso da terra: Floresta Estacional sempre-verde, Cerrado e Usos Antrópicos. No software ArcGis, definiu-se as escalas por meio da ferramenta multibuffer com raio de 50, 500 e 1000 metros no entorno de cada ponto de coleta. As coletas foram do tipo simples, de superfície em 9 pontos dos principais afluentes da bacia. A ANOVA indicou diferença significativa da Turbidez nos períodos de chuva e seca, o que não ocorreu com os Sólidos Totais. As análises indicaram correlação negativa entre Sólidos totais e a classe Floresta Estacional sempre-verde e a similaridade em relação aos Sólidos Totais e a Turbidez está sendo influenciada pela distância espacial entre os pontos. da água.

Palavras-chave: Escala. Rio Paraguai. Processamento de imagens. Qualidade

\section{INTRODUCTION}

Tropical forests play an important role to maintain biodiversity, water resources and carbon stocks (MAHMOOD et al., 2014, n.p.; LAWRENCE; VANDECAR, 2015, p. 27). However, due to the expansion of settlements, agricultural activities, logging, opening of roads and mining, these forests are among the most deforested areas of the Earth (FEARNSIDE, 2005, p.114).

Despite the reduction of deforestation rates in recent years, Mato Grosso State, which encompasses the Pantanal, Cerrado and Amazon biomes, is one of the most affected regions by the consequences of deforestation (FEARNSIDE, 2016, p.34). In this context, the loss of forest cover and the inadequate use of soil and water are among the main actual environmental problems.

According to Metzger (2001, p.7), for the sustainable development of a given region, it is necessary to devise adequate strategies for both land use and the conservation of the landscape as a whole. Therefore, to understand the ecological processes related to the loss of forest cover, multi-scale analysis is extremely important (GIBSON et al., 2000).

Loss of water resources quality can determine the water quality of a region. This can be caused by natural processes such as rain, erosion and sediment transport; or as a consequence of human action such as urbanization, industrialization and agriculture (SINGH et al., 2009, p. 889).

Zhou et al. (2012, p. 167) argue that changes in land use can modify the geomorphological characteristics and intensify the pollution sources in river systems. This change becomes a decisive factor for the water quality of rivers in a river basin. Although changes do not occur uniformly in all regions, the extent and characteristics of land use impacts and quality changes vary according to the adopted scale (TU; XIA, 2006, p. 34). 
For Machado et al. (2003, p. 731, 732), the presence of native vegetation is essential to conserve water resources. Native vegetation reduces the velocity of the surface runoff resulting in a decrease in sediment transport capacity, preventing them to reach the drainage network. The early deposition of sediments and the presence of riparian forest act as a protective barrier to the sediments and as a filter, retaining part of the sediments.

Many studies seek to answer how changes in land use affect water quality. To perform this task, the relationships between land use and water quality indicators at various spatial scales are analyzed (TU; XIA, 2006), such as the use of the basin scale (SLIVA; WILLIAMS, 2001, p. 3462), and the influence of the riparian forest scale on the sediment retention (HOOK, 2003, p. 1130).

In this context, studies that have a strategic vision for the preservation, demonstrating the influence of the vegetal cover on the water quality are necessary.

This study investigates the Paraguay/Diamantino basin, an important area in the Pantanal Biome, considered one of the largest wetlands from the planet and declared as a national patrimony by the Brazilian Federal Constitution of 1988 (BRASIL, 1988, on-line) and Biosphere Reserve (UNESCO, 2000, on-line).

The colonization of this region began in 1728, with gold and diamond mining, driving migration to this area. Until the 1960s its economic base was mining, subsistence farming and elementary cattle ranching (CASARIN, 2007, p. 36; ZOLINGER et al., 2002 , p. 31). Casarin (2007, p.37) reported that economic activities, especially mining, were responsible for the change in the landscape of the region.

The inadequate use of soil and water resources generated a large amount of sediment. Over the years, it caused silting of rivers and fluctuations in flood patterns in the Pantanal plain. Eventual changes in water quality and the hydrological regime of the surrounding plateau can have important impacts in the Pantanal region (ALLASIA, et al., 2004, p. 2; CUNHA; JUNK, 2004, p. 107). In this context, the objective of this study is to evaluate the influence of land use and land occupation in different scales on the surface water quality of the Paraguay/Diamantino Basin, Mato Grosso State, Brazil.

\section{METHODS AND MATERIALS}

\section{Study Area}

The Paraguai/Diamantino Basin (PDB) has an area of $695.00 \mathrm{~km}^{2}$, located in the north central part of Mato Grosso State, between the geographical coordinates WGr 56'28'29" - 56030'55" and S 14027'22" - 14022'55, comprising the region of the sources of the Paraguay River (Figure 1).

PDB is inserted in the municipalities of Alto Paraguay and Diamantino, totaling 8 sub-basins whose main tributaries are: Paraguay River, Rio Diamantino, Rio Manoel, Ribeirão Buriti, Ribeirão Mato Seco, Ribeirão Macaco, Ribeirão Amolar and Ribeirão Melgueira. 


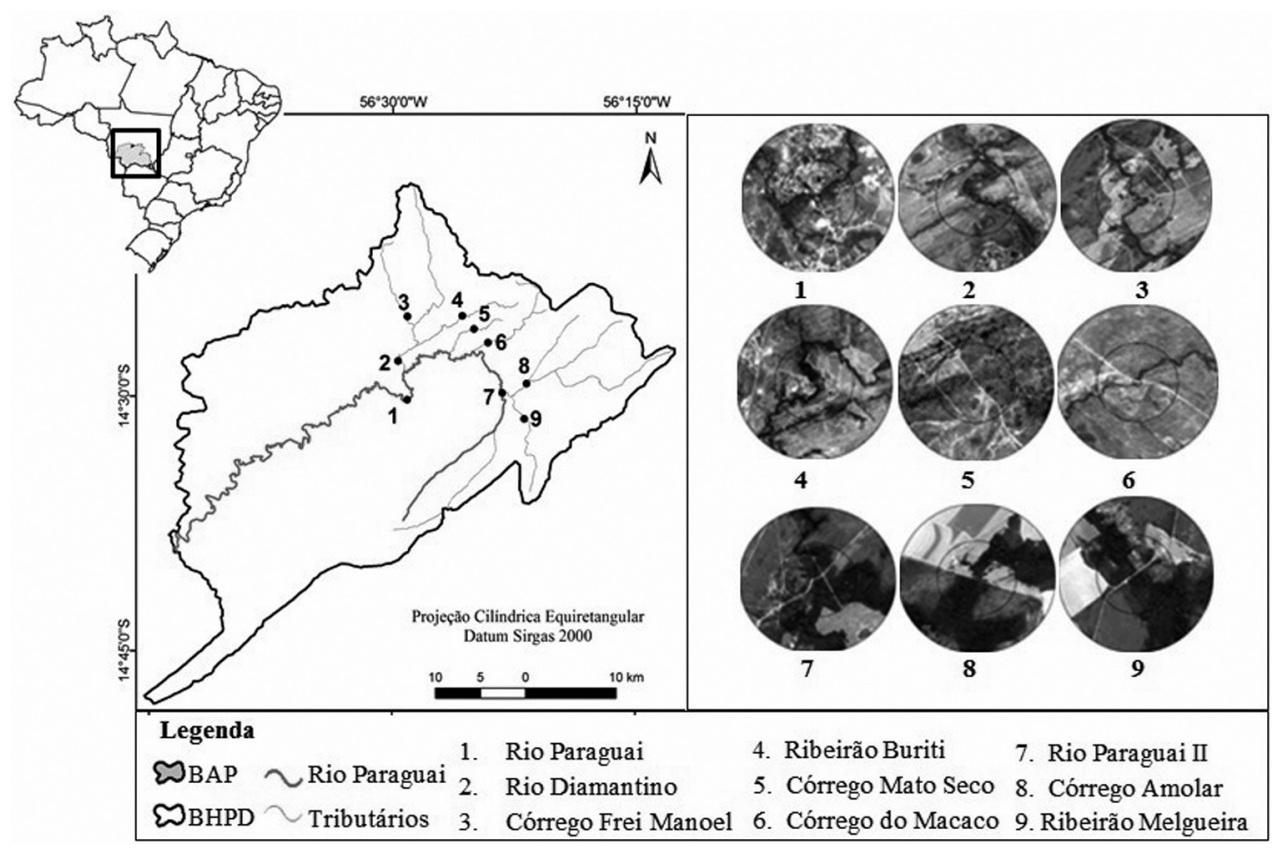

Figure 1 - Location of the Paraguay/Diamantino Basin Mato Grosso State, Brazil

The predominant climate of the region, according to the Köppen classification, is the Tropical Savanna tropical, with average annual temperatures varying between 22.5 and $26.5^{\circ} \mathrm{C}$. The region has two well-defined seasons, from November to March (rainfall) and from April to October (drought). The average annual rainfall is 1,398 $\mathrm{mm}$, ranging from $800 \mathrm{~mm}$ to $1,600 \mathrm{~mm}$ (CALHEIROS; OLIVEIRA, 2010, p. 121; CASARIN, 2007, p. 40).

The vegetation is of Evergreen Seasonal Forest (ESF), whose core area is the extensive Parecis Plateau, occurring until the Paraguay River Depression. This type of vegetation presents more vigor in the dry season, besides the Cerrado, which predominates in the region (IBGE, 2012, on-line).

Casarin and Santos (2005, p. 4) define the hydrographic network of the PDB basin as dense with small channels of low water flow and clear water almost every year. This area has a strategic location in the environmental and regional context, as it forms part of the watershed of the Paraguay and Amazon basins. Casarin and Santos (2005, p. 2) consider it as "a dispersing field of flows and consequently the effect of environmental degradation in this area will extend along the basin".

PDB has a population of approximately 30 thousand inhabitants. Its main economic activities are agriculture, cattle raise, mineral extraction and swine breeding (IBGE, 2010, on-line). 


\section{Methodological procedures}

Visits were made to the area under study in February and April 2016 for water collection, photographic records of land use types and land cover in the region, and also for the collection of Land Control Points (LCP) to subsidize the classification of satellite images.

The PDB was delimited by topography data of the Digital Elevation Model (DEM) using the Shuttle Radar Topography Mission (SRTM) data with spatial resolution of 30m (BRUBACHER et al., 2012,p. 386). This data was obtained in the geomorphometric database of Brazil, from the TOPODATA project (VALERIANO, 2008, p.21) available from the National Institute of Space Research (INPE).

For the analysis of land use and land cover, RapidEye satellite images were acquired with a spatial resolution of 6.5 meters, available from the Ministry for the Environment (MMA). Ten scenes of RapidEye images from 2013 and 2014 (when the images were available) were acquired from PDB. The clipping of the area under study area was performed by importing the PDB mask in the shapefile extension.

The unsupervised image classification was performed in ArcGIS software, version 10.1 (ESRI, 2012, on-line) using the ISOSEG method, which is a non-supervised data grouping algorithm, applied on a set of regions. These regions are characterized by its statistical attributes of average, covariance matrix and area (CRÓSTA, 1992, p. 114).

Through the observation of these images and the methodology proposed by the Technical Manual of Land Use (IBGE, 2006, p. 90) and the Technical Manual of Brazilian Vegetation (IBGE, 2012, p. 20) three land use classes were defined: Evergreen Seasonal Forest (ESF) (including riparian forest), Cerrado and Human Use (Agriculture, Urban, Mining).

In order to analyze the quality of the water, 9 collection points were selected, distributed in the Paraguay River, downstream of the main tributaries from the basin described in Figure 1. Parameters were analyzed which express the physical characteristics of the water, such as: Turbidity (Tu) and Total Solids (ST). The water collections of the simple type were carried out in February 29 and April 25, 2016, from the surface and were taken at a depth of $0.30 \mathrm{~m}$, avoiding the margins. A flask was immersed with its opening in the anti-flow direction. The samples were conditioned in a styro-foam box with ice, at $4^{\circ} \mathrm{C}$, during its transportation to the laboratory for analysis. The collection and preservation of the samples followed the standards of the Environmental Sanitation Technology Company (CETESB) (SÃO PAULO, 1987, p. 137).

In order to investigate the area of influence of land use in relation to the physical variables, the multiscale approach was used. For the RapidEye image analysis, the multibuffer tool, available in the ArcGis software, was used to define the distance radius of $50 \mathrm{~m}, 500 \mathrm{~m}$ and $1000 \mathrm{~m}$ in the vicinity of each collection point.

The statistical analysis was done, considering the normality of the parameters of water quality and land use/land occupation classes, using the Kolmogorov-Smirnov test, applying the normalization of the data when necessary, using the transformation. $\log (x+1)$

The Analysis of Variance (ANOVA) was used to verify evidence of ST and Tu differences between rainy and dry periods.

Pearson correlation coefficients were estimated between ST and Tu and the amount of each land use class, in the three scales, for rainy and dry periods. When the correlations were significant $(p<0.05)$, the simple linear regression models were adjusted.

For the evaluation of the similarity between ST and Tu values and collection points, a similarity matrix was obtained through the Bray-Curtis coefficient. The same 
matrix was correlated with a spatial distance matrix between the collection points and the significance was verified through the Mantel permutation test with 1000 randomisations.

The analysis was performed in the R (CORE TEAM, 2015) programs, applying the Vegan package (OKSANEN et al., 2015, p. 34).

\section{RESULTS AND DISCUSSION}

From the classification of the multi-buffers it was possible to observe in the scale of $50 \mathrm{~m}$ the predominance of the ESF class in 5 points $(1,2,7,8$ and 9) followed by the Cerrado class in 4 points $(3,4,5,6)$. The Anthropic Use class did not prevail in any of the points studied. In the $500 \mathrm{~m}$ scale, it was observed that the ESF class had the greatest extension (in area) in only 3 points (7,8 and 9). The Cerrado class stood out in 4 points $(1,2,5$ and 6$)$ and Anthropic Use prevailed in 2 points ( 3 and 4$)$. In the $1000 \mathrm{~m}$ scale, the ESF class presented a larger area in 3 points (7, 8 and 9), the Cerrado class revealed a domain in 5 points $(1,2,3,5$ and 6$)$ and the Anthropic Use class only in point 4 (Table 1 and Figure 2).

\section{Table1 - Percentage of land use per point at multi-buffer scale}

\begin{tabular}{|c|c|c|c|c|c|c|c|c|c|c|}
\hline \multirow{3}{*}{ Scale } & \multirow{3}{*}{ Classes } & \multicolumn{9}{|c|}{ Pontos de coleta } \\
\hline & & 1 & 2 & 3 & 4 & 5 & 6 & 7 & 8 & 9 \\
\hline & & $(\%)$ & $(\%)$ & $(\%)$ & $(\%)$ & $(\%)$ & $(\%)$ & $(\%)$ & $(\%)$ & $(\%)$ \\
\hline \multirow{3}{*}{50} & FESV & 43,8 & 69,1 & 23,8 & 31,2 & 0,1 & 11,4 & 66,4 & 71,2 & 66,6 \\
\hline & Cerrado & 42,2 & 30,4 & 52,0 & 39,0 & 62,1 & 48,7 & 19,0 & 22,0 & 19,2 \\
\hline & UA & 13,9 & 0,5 & 24,2 & 29,9 & 37,8 & 40,0 & 14,6 & 6,9 & 14,3 \\
\hline \multirow{3}{*}{500} & FESV & 27,8 & 25,7 & 14,0 & 13,9 & 0,4 & 3,3 & 72,8 & 45,5 & 68,3 \\
\hline & Cerrado & 40,4 & 43,8 & 39,1 & 33,2 & 67,7 & 58,1 & 20,8 & 23,2 & 20,7 \\
\hline & UA & 31,9 & 30,6 & 46,9 & 52,9 & 31,9 & 38,6 & 6,4 & 31,3 & 11,1 \\
\hline \multirow{3}{*}{1000} & FESV & 21,3 & 16,2 & 15,9 & 6,1 & 1,0 & 3,0 & 45,9 & 48,7 & 48,2 \\
\hline & Cerrado & 44,0 & 43,4 & 48,0 & 31,9 & 62,3 & 63,2 & 42,5 & 23,7 & 30,0 \\
\hline & UA & 34,7 & 40,3 & 36,1 & 62,0 & 36,8 & 33,8 & 11,6 & 27,6 & 21,8 \\
\hline
\end{tabular}

FESV $=$ Evergreen Seasonal Forest, UA $=$ Anthropogenic Uses.

Analyzing the average percentage of each class within the buffers, one verifies that in the buffer of $50 \mathrm{~m}$, the Anthropic Use class was less representative and that the ESF was the dominant class. This result indicates that, in general, the surroundings of the collection points have a good forest cover (ESF and Cerrado).

On the other hand, as one increases the scale $(500 \mathrm{~m}$ and $1000 \mathrm{~m})$ it is possible to observe that the percentage of the ESF decreases in relation to the other two and that the Human Use, in turn increased (Figure 3). 


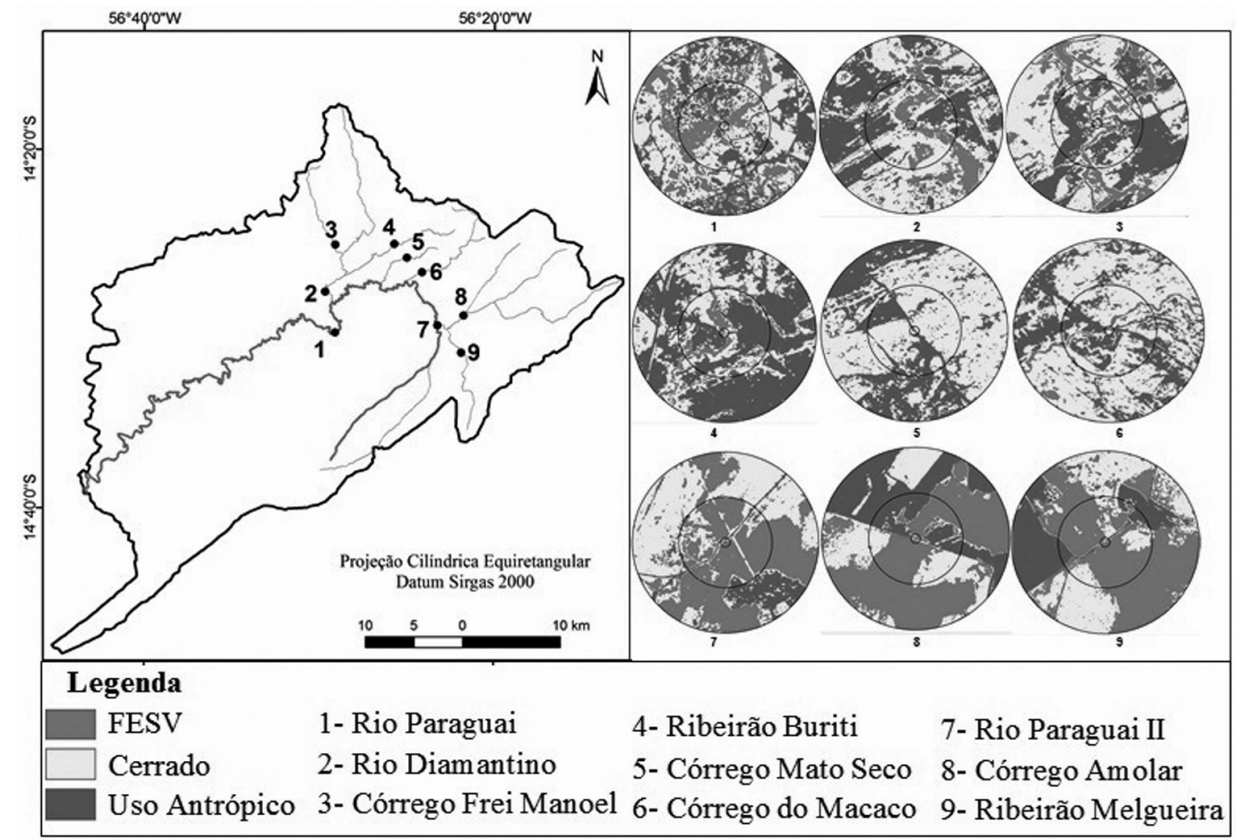

Figure 2 - Land use classification in the Paraguay/Diamantino River Basin

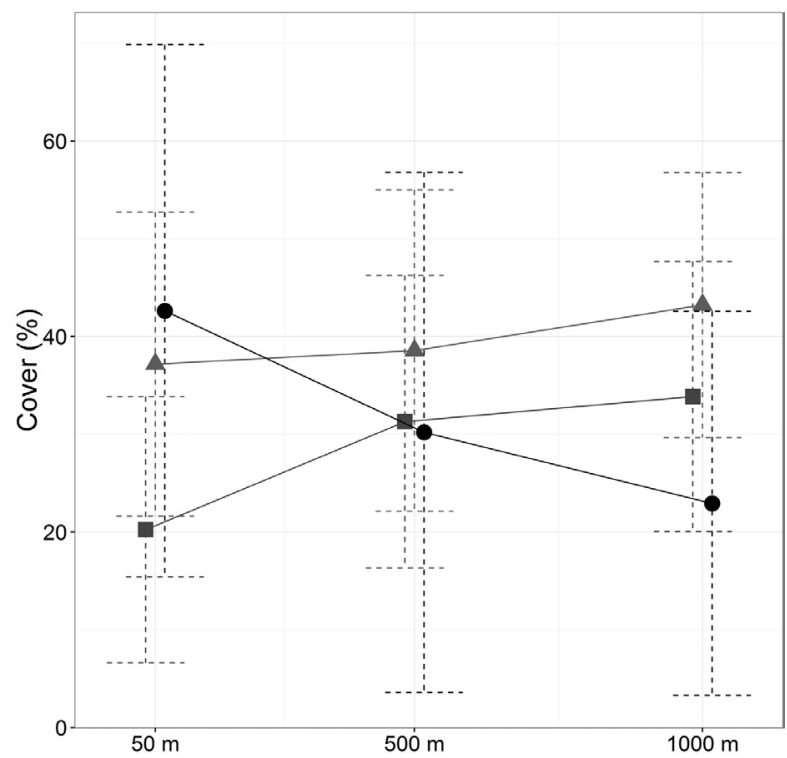

Figure 3 - Coverage percentage $(E S F=0$, Cerrado $=\Delta$, Human Use $=\square$ ).

In buffers of $50 \mathrm{~m}, 500 \mathrm{~m}$ and $1000 \mathrm{~m}$ around collection points in the Paraguay / Diamantino Basin - MT, Brazil 
The changes described in the $500 \mathrm{~m}$ and $1000 \mathrm{~m}$ buffers are supported by studies from Casarin (2007, p. 8) and Alho (2011, p. 337) in the Upper Paraguay Basin, which point out that the practice of mechanized agriculture and pasture over the years has led to intense deforestation, mainly due to monocultures. Currently, soybean and pasture are predominant in source regions of the Paraguay River, where the loss of about $60 \%$ of its natural vegetation cover is verified, as well as the mining activity, which left marks with extensive excavations in the region.

In the $1000 \mathrm{~m}$ scale, the Cerrado class has a greater expression, cited by Brazil (2006) as the predominant vegetation in the region. The Human Use class on this scale influences the urban area and mining.

Casarin (2007, p. 20) describes that the city of Alto Paraguay emerged with the gold rush. Its ephemeral development is typical for mining sites. In addition to the environmental impacts left by mining, they are now a social problem. The holes left create residues that lead to the sediments and contaminate the water of the rivers. This occurs mainly with mercury, which is used for gold amalgamation in all mines. Mineral extractivism still remains one of the main economic activities of the municipality (IBGE, 2010, on-line).

The marks of the excavation are still visible today along the bed of the Paraguay River, which is the main source of supply for the municipality of Alto Paraguay, besides water wells. Water extraction for human use is carried out on the water line/direct outlet. It is considered as satisfactory, because it has an isolated system: a water source or mixed according to data of the National Water Agency (ANA) (ANA, 2015, on-line).

These changes, both localized and diffuse in this hydrographic region, are expressed in water bodies. They are considered as the main reflections of the physiographic characteristics and the processes of land use/land occupation of the soil in the drainage area, and can be verified by monitoring the water quality (BRASIL, 2006, p. 45).

Table 2 shows results obtained for the water quality parameters at analyzed points. The total solids behavior is analogous to that of turbidity, and both are related (BUZELLI; CUNHA-SANTINO, 2013, p.193).

During rainfall turbidity results ranged from 4.3 to 266 (NTU) and Total Solids from 16 to 240 ( $\mathrm{mg} / \mathrm{L}$ ). During dry periods, turbidity values ranged from 0.64 to 12.7 (NTU) and total solids from 57, 77 to 195, 55 (mg / L).

\section{Table 2 - Results from water quality analysis for rainy and dry periods}

\begin{tabular}{|c|c|c|c|c|c|c|c|c|c|c|}
\hline \multirow{2}{*}{ Period } & \multirow{2}{*}{$\begin{array}{c}\text { * Parameters } \\
\text { from water }\end{array}$} & \multicolumn{9}{|c|}{ Collection points } \\
\hline & & 1 & 2 & 3 & 4 & 5 & 6 & 7 & 8 & 9 \\
\hline \multirow{2}{*}{ Rain } & $\mathrm{Tu}$ & 266 & 131 & 8,52 & 236 & 14,3 & 83,5 & 15,2 & 16,4 & 4,3 \\
\hline & ST & 240 & 152 & 74 & 134 & 106 & 70 & 64 & 23,38 & 16 \\
\hline \multirow{2}{*}{ Drought } & $\mathrm{Tu}$ & 12,7 & 7,36 & 0,64 & 9,28 & 3,89 & 3,13 & 0,92 & 3,09 & 1,4 \\
\hline & ST & 108,55 & 73,33 & 82,22 & 88 & 195,55 & 133,33 & 68,88 & 100 & 57,77 \\
\hline
\end{tabular}

*Turbidity $=\mathrm{Tu}$ and Total Solids $=$ TS.

Tu differed significantly between rainfall and dry periods ( $p<0.05$, ANOVA, Tukey post-hoc). This was expected since the literature lists higher values from this parameter in periods with higher precipitation, besides the intensity and frequency of 
rainfall. Higher amounts of sediments, soil particles carried to the watercourse, cause the increase of suspended material in the river and encourage the elevation of Turbidity (ROCHA et al., 2014, p. 134; OLIVEIRA, 2013, p. 26). TS did not differ significantly between the two periods.

As verified by values of correlation analysis, only TS were affected by the amount of coverage and only during the dry season. In the three buffers analyzed, the relationship between TS and ESF was negative, ergo, the higher the amount of $E S F$, the smaller the amount of TS. This result may indicate that the vegetation permanence acts as a protective barrier to the sediments, reducing the flow velocity, acting as a filter, retaining part of the sediments (MACHADO et al., 2003, p. 731).

The relationship with Cerrado was positive in buffers 50 and $500 \mathrm{~m}$, and with Anthropic Use only in the buffer of $50 \mathrm{~m}$. This indicates that the higher the amount of anthropic area, the greater the amount of TS (Table 3, Figure 4). The absence of protection that riparian vegetation areas cause on the protection of water bodies is evident. The points with higher values, have higher concentrations of organic and inorganic sediments carried to bodies of water, ergo, indicating that the local is more polluted (CABRAL et al., 2015, p. 119; (ALMEIDA; SCHWARZBOLD, 2003, p. 88).

Increased TS can cause damage to aquatic life. It indicates sedimentation in riverbeds extinguishing organisms that provide food, besides damaging the places of fish spawning. The solids can retain bacteria and organic residues in the bottom of the rivers, generating anaerobic decomposition (CETESB, 2009, p. 4).

\section{Table 3 - Correlation analysis (Pearson) between Turbidity and Solid variables and the amount of coverage (ha) for each cover class, in the three scales studied $(50,500$ and $1000 \mathrm{~m})$, in the dry and rainy periods $(*=p<0.05)$}

\begin{tabular}{|c|c|c|c|c|c|c|c|c|c|c|c|c|c|}
\hline & \multicolumn{6}{|c|}{ DRY SEASON } & \multicolumn{6}{|c|}{ RAIN SEASON } \\
\hline & & \multicolumn{2}{|c|}{50} & \multicolumn{2}{|c|}{500} & \multicolumn{2}{|c|}{1000} & \multicolumn{2}{|c|}{50} & \multicolumn{2}{|c|}{500} & \multicolumn{2}{|c|}{1000} \\
\hline & & $\mathbf{r}$ & $\mathbf{p}$ & $\mathbf{r}$ & $\mathbf{p}$ & $\mathbf{r}$ & $\mathbf{p}$ & $\mathbf{R}$ & $\mathbf{p}$ & $\mathbf{r}$ & $\mathbf{p}$ & $\mathbf{r}$ & $\mathbf{P}$ \\
\hline FSVE & $\mathbf{T u}$ & -0.01 & 0.99 & -0.06 & 0.88 & -0.16 & 0.68 & -0.02 & 0.95 & -0.01 & 0.97 & -0.13 & 0.73 \\
\hline & ST & -0.79 & $0.01 *$ & -0.89 & $0.01 *$ & -0.83 & $0.001 *$ & -0.15 & 0.69 & -0.17 & 0.65 & -0.24 & 0.52 \\
\hline Cerrado & $\mathbf{T u}$ & 0.2 & 0.6 & 0.28 & 0.46 & -0.93 & 0.93 & 0.18 & 0.64 & 0.22 & 0.57 & -0.02 & 0.95 \\
\hline & ST & 0.76 & $0.01 *$ & 0.77 & $0.01 *$ & 0.59 & 0.09 & 0.4 & 0.29 & 0.45 & 0.22 & 0.31 & 0.42 \\
\hline UA & Tu & -0.12 & 0.75 & 0.41 & 0.27 & 0.52 & 0.14 & -0.11 & 0.76 & 0.4 & 0.28 & 0.53 & 0.13 \\
\hline & ST & 0.73 & $0.02 *$ & 0.45 & 0.22 & 0.43 & 0.24 & -0.3 & 0.94 & 0.38 & 0.31 & 0.55 & 0.12 \\
\hline
\end{tabular}


The linear regression analysis was used to obtain the coefficient of determination (R20) and slope of the line, when the correlation was significant (Figure 4).

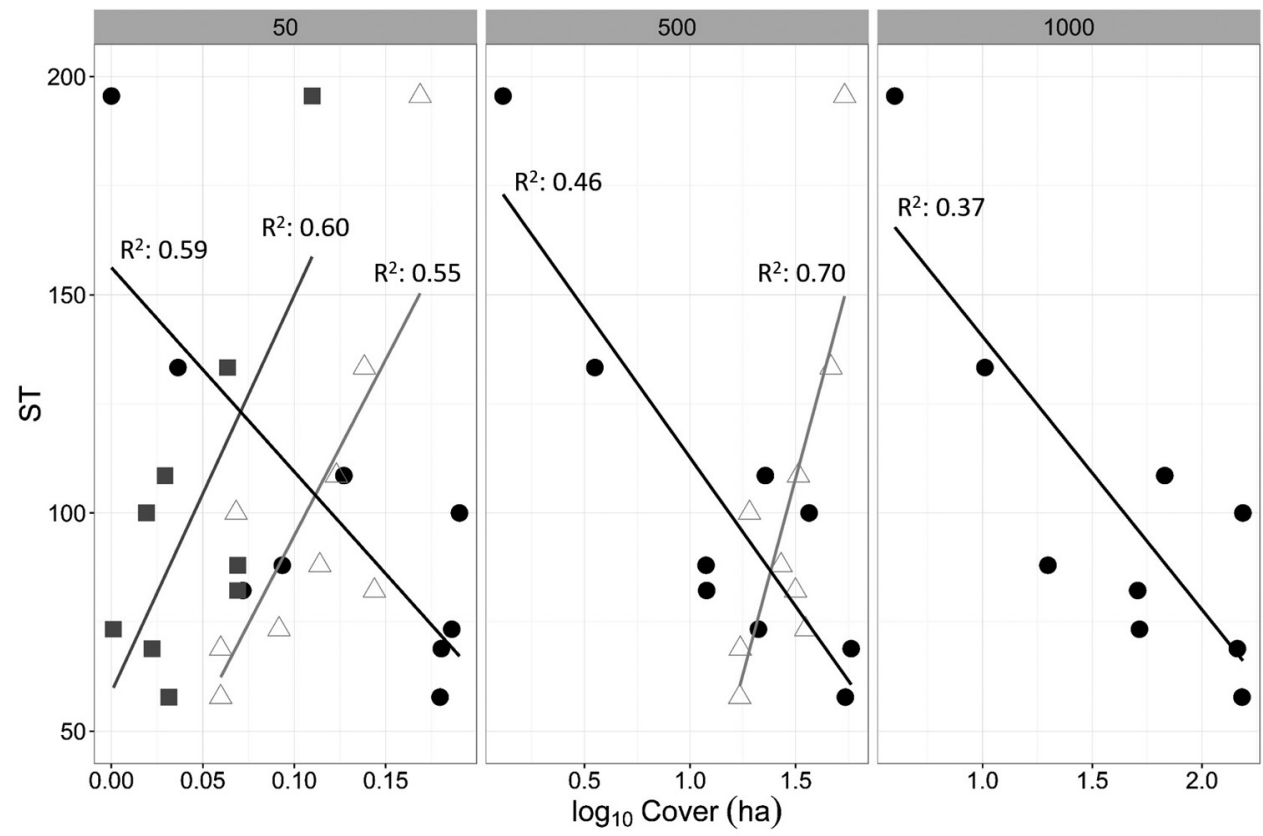

Figure 4 - Linear regression between TS and the amount of coverage (ha), in the three scales studied (circle = ESF, triangle = Cerrado and square = Anthropic Uses)

Using the Mantel test, the similarity in relation to TS and Tu was verified as being influenced by the spatial distance between the points (Mantel test $r=0.3696$ $p=0.033$ ). That is, closer points are more similar (Figure 5).

Points 1,2 and 4 are spatially close, in addition to those that are under direct influence of urban areas of the municipalities Alto Paraguay and Diamantino, presenting consequently the highest Tu and TS values in the rainy season. Conversely they present the lowest Tu and TS results in the dry season. Points 7, 8 and 9 are more distant from cities and closer to mining sites, where the anthropic influence in these points is due to the presence of agricultural areas, confirming the results obtained.

This result suggests that urban areas and land use when adjacent to collection points have a greater influence on water quality (TU; XIA, 2006, p. 38). 


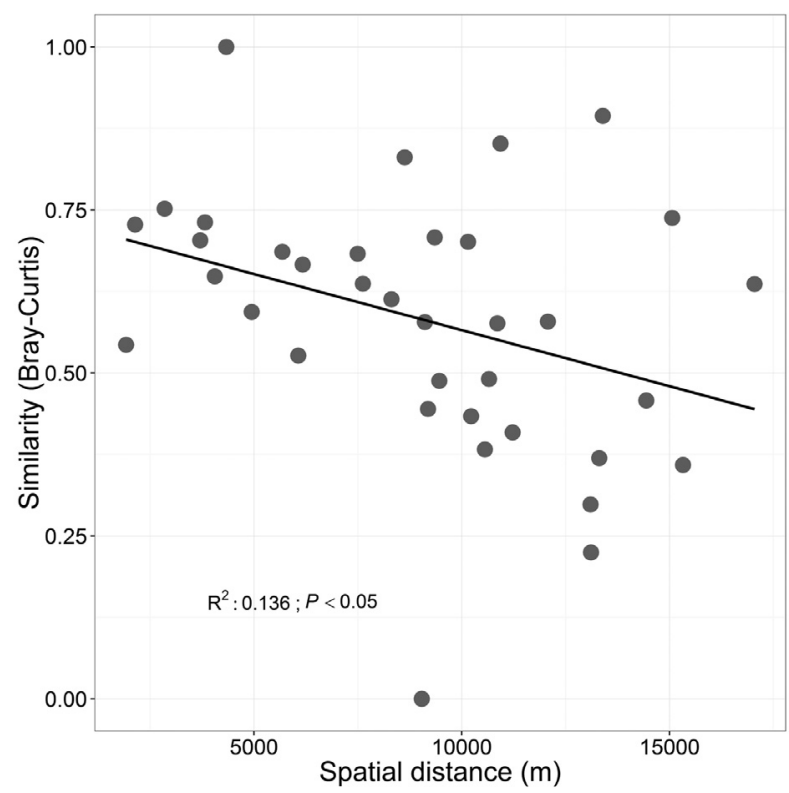

Figure 5 - Relationship between Tu and TS similarity of collection points and spatial distance. (Each point in the graph represents a pair of comparative sample points)

\section{CONCLUSIONS}

The points in the $50 \mathrm{~m}$ scale maintain the permanent preservation areas, as established by legislation. There is seasonal influence on Turbidity. The increase of total solids is influenced by the reduction of vegetation.

The presence of the urban area near the Paraguay River requires attention, as it may be compromising the water quality, as observed in the rainy season results, mainly because of the importance of public supply this river provides to the population.

The present study contributes to understand the impact of land use on the quality of surface water and proposes a more in-depth investigation of the analysis of water resources in river basins.

\section{ACKNOWLEDGEMENTS}

To the Coordination for the Improvement of Higher Education Personnel (Capes) for a grant to a master degree scholarship. 


\section{REFERENCES}

ALHO, C. J. R. Concluding remarks: overall impacts on biodiversity and future perspectives for conservation in the Pantanal biome. Brazilian Journal Biology, v. 71, n. 1, p. 337-341, 2011.

ALLASIA, D. G.; COLLISCHONN, W.; TUCCI, C. E. M; GERMANO, A.; COLLISCHONN, B.; FAILACHE, N. Modelo hidrológico da bacia do Alto Paraguai. In: SIMPÓSIO DE RECURSOS HÍDRICOS DO CENTRO-OESTE, V. 3, Goiânia. Anais... Porto Alegre (RS), 2004.

ALMEIDA, M. B.; SCHWARZBOLD, A. Avaliação sazonal da qualidade das águas do Arroio da Cria Montenegro, RS com aplicação de um índice de qualidade de água (IQA). Revista Brasileira de Recursos Hídricos, v. 8, n. 01 p. 81- 97, 2003.

ANA. Agência Nacional das Águas. Portal da qualidade das águas, 2015. Available at: <http://atlas.ana.gov.br/Atlas/forms/Home.aspx>. Access in June $22^{\text {nd }}$ 2016.

BRASIL, Ministério do Meio Ambiente. Caderno da Região Hidrográfica do Paraguai / Ministério do Meio Ambiente, Secretaria de Recursos Hídricos. Brasília: MMA, 2006. 140 p.

BRASIL. Constituição da República Federativa do Brasil, 1988.

BRUBACHER, J. P., de OliveirA, G. G., GUASSELLI, L. A., \& LUERCE, T. D. Avaliação de bases SRTM para extração de variáveis orfométricas e de drenagem. Geociências, v. 31, n. 3, p. 381-393, 2012.

BUZELLI, G. M.; CUNHA-SANTINO, M. B. Análise e diagnóstico da qualidade da água e estado trófico do reservatório de Barra Bonita (SP). Ambi-Agua, Taubaté, v. 8, n. 1, p. 186-205, 2013.

CABRAL, J. B. P., DA ROCHA, I. R., NOGUEIRA, P. F., E BECEGATO, V. A.. Avaliação sazonal e monitoramento das águas do Rio Doce-GO. Geoambiente On-line, n. 24, 2015.

CALHEIROS, D. F.; OLIVEIRA, M. D. O Rio Paraguai e sua planície de inundação: o Pantanal Mato-grossense. Ciência \& Ambiente, n. 41, p. 113-130, 2010.

CASARIN, R. Caracterização dos principais vetores de degradação ambiental da bacia hidrográfica Paraguai/Diamantino. 2007. 169 f. Tese (Doutorado em Geografia) - Universidade Federal do Rio de Janeiro, Rio de Janeiro, 2007.

CASARIN, R. SANTOS, S. Características ambientais na área das nascentes do rio Paraguai. In: SIMPÓSIO NACIONAL DE GEOGRAFIA AGRÁRIA, 3 - SIMPÓSIO INTERNACIONAL DE GEOGRAFIA AGRÁRIA JORNADA ARIOVALDO UMBELINO DE OLIVEIRA, 2, Presidente Prudente, 2005. Anais... Presidente Prudente: Unesp, 2005.

COMPANHIA, DE TECNOLOGIA DE SANEAMENTO AMBIENTAL (CETESB). Significado ambiental e sanitário das variáveis de qualidade das águas e dos sedimentos e metodologias analíticas e de amostragem. Qualidade das águas interiores no Estado de São Paulo, 2009.

CRÓSTA, A. P. Processamento digital de imagens de sensoriamento remoto. São Paulo, 173p. 1992. Tese de Doutorado - Instituto de Geociências, Universidade de Campinas.

CUNHA, C. N.; JUNK, W. J. Year-to-year changes in water level drive the invasion of Vochysia divergence in Pantanal glassland. Applied Vegetation Science, Grangärde, v.7, n.1, p. 103-110, 2004. 
E. S. R. I. ArcGis . 10.1. Redlands, California: ESRI, 2012.

FEARNSIDE, P. M. Desmatamento na Amazônia brasileira: história, índices e conseqüências. Megadiversidade, v. 1, n. 1, p. 113-123, 2005.

FEARNSIDE, P. M. Environmental policy in Brazilian Amazonia: Lessons from recent history. Novos Cadernos NAEA, v. 19, n. 1, 2016.

GIBSON, B. K.; MALONEY, P. R.; SAKAI, S. Has blending compromised cepheid-based determinations of the extragalactic distance scale?. The Astrophysical Journal Letters, v. 530, n. 1, p. L5, 2000.

HOOK, P. B. Sediment retention in rangeland riparian buffers. Journal of Environmental Quality, v. 32, n. 3, p. 1130-1137, 2003.

IBGE, Instituto Brasileiro de Geografia e Estatística. Estimativa da população residente de Mato Grosso. Diamantino, 2010. Available at: <http:// www. cidades.ibge.gov.br/xtras/perfil.php?lang $=\&$ codmun $=510350 \&$ search $=$ matogrosso|diamantino>. Access in March 30 2016.

IBGE, Instituto Brasileiro de Geografia e Estatística. Manual técnico de uso da terra. Rio de Janeiro: IBGE, 2006.

IBGE, Instituto Brasileiro de Geografia e Estatística. Manual técnico de vegetação brasileira. Rio de Janeiro: IBGE, 2012.

LAWRENCE, D.; VANDECAR, K. Effects of tropical deforestation on climate and agriculture. Nature Climate Change, v. 5, n. 1, p. 27-36, 2015.

LIRA, G. Conhecendo Mato Grosso XXI. Microrregiões de Parecis Munícipios de Mato Grosso. 2011. 43p.

MACHADO, R. E.; VETORAZZI, C. A.; XAVIER, A. C. Alternative scenario simulation of land use in a watershed through geoprocessing and modeling techniques. Revista Brasileira de Ciência do Solo, v. 27, n. 4, p. 727-733, 2003.

MAHMOOD, R., PIELKE, R. A., HUBBARD, K. G., NIYOGI, D., DIRMEYER, P. A., MCALPINE, C., ... E BAKER, B. Land cover changes and their biogeophysical effects on climate. Int. J. Climatol. v. 34, p. 929-953, 2014.

METZGER, J. P. O que é ecologia de paisagens? In www. Biotaneotropica. org. br. Publicado em, v. 28, n. 11, p. 2001, 2001.

OKSANEN, J.; F. BLANCHET, G. ;; FRIENDLY, M.; LEGENDRE,R.K P.; MCGLINN, D.; MINCHIN,P.; O'HARA, R. B; SIMPSON, G. L.; SOLYMOS, P. M.; HENRY, H.; STEVENS, E.S. WAGNER. Vegan: Community Ecology Package. R package version 2.4-1. 2016. https://CRAN.R-project.org/package=vegan

OLIVEIRA, J. M. Qualidade da água superficial em microbacias com diferentes usos de solo no município de Itaara - RS. $84 \mathrm{p}$. Dissertação (Mestrado em Geografia) -Universidade Federal de Santa Maria, 2013.

ROCHA, H. M.; CABRAL, J. B. P.; BRAGA, C. C. Avaliação Espaço-Temporal das Águas dos Afluentes do Reservatório da UHE Barra dos Coqueiros/Goiás. RBRH - Revista Brasileira de Recursos Hídricos, v. 19 n.1, p. 131-142, 2014.

SÃo PAULO. Companhia Ambiental do Estado de São Paulo. Guia de coleta e preservação de amostras de água. Cetesb, 1987.

SINGH, K. P.; BASANT, A.; MALIK, A.; JAIN, G. Artificial neural network modeling of the river water quality: a case study. Ecological Modelling, v. 220, n. 6, p. 888-895, 2009. 
SLIVA, L.; WILLIAMS, D. D. Buffer zone versus whole catchment approaches to studying land use impact on river water quality. Water research, v. 35, n. 14, p. 3462-3472, 2001.

TU, J.; XIA, Z. G. Assessing the impact of land use changes on water quality across multiple spatial scales in eastern Massachusetts. Middle States Geographer, v. 39, p. 34-42, 2006.

UNESCO. Biosphere Reserve Information - The Pantanal Biosphere Reserve. MAB - Man and Biosphere Programme. Biosphere Reserves Directory, 2000.

VALERIANO, M. M. Topodata: guia para utilização de dados geomorfológicos locais. São José dos Campos, 2008.

ZHOU, T.; WUB,J.; PEN, S. Assessing the effects of landscape pattern on river water quality at multiple scales: A case study of the Dongjiang River watershed, China. Ecological Indicators, v. 23, p. 166-175, 2012.

ZOLINGER, I.T.; SVISERO, D. P.; WESKA, R. K.. Morfologia cristalina de diamantes provenientes das regiões de Chapada dos Guimarães, Poxoréu, Paranatinga, Diamantino e Alto Paraguai, Mato Grosso. Revista do Instituto Geológico, v. 23, n. 2, p. 23-33, 2002. 